\title{
Gold lon-Angiotensin Peptide Interaction by Mass Spectrometry
}

\author{
Jenny Lee, ${ }^{1}$ Lasanthi P. Jayathilaka, ${ }^{2}$ Shalini Gupta, ${ }^{2}$ Jin-Sheng Huang, ${ }^{2}$ Bao-Shiang Lee ${ }^{2}$ \\ ${ }^{1}$ Illinois Mathematics and Science Academy, 1500 Sullivan Rd, Aurora, IL 60506-1000, USA \\ ${ }^{2}$ Protein Research Laboratory, Research Resources Center, University of Illinois at Chicago, 835 S. Wolcott Avenue, Chicago, IL \\ 60612, USA
}

\begin{abstract}
Stimulated by the interest in developing gold compounds for treating cancer, gold ionangiotensin peptide interactions are investigated by mass spectrometry. Under the experimental conditions used, the majority of gold ion-angiotensin peptide complexes contain gold in the oxidation states I and III. Both ESI-MS and MALDI-TOF MS detect singly/multiply charged ions for mononuclear/multinuclear gold-attached peptides, which are represented as [peptide $+\mathrm{a} \mathrm{Au}$ $(\mathrm{I})+\mathrm{b} A u(I I I)+(e-a-3 b) H]^{e+}$, where $a, b \geq 0$ and e is charge. ESI-MS data shows singly/multiply charged ions of $\mathrm{Au}(\mathrm{I})$-peptide and $\mathrm{Au}(\mathrm{III})$-peptide complexes. This study reveals that MALDITOF MS mainly detects singly charged $\mathrm{Au}(\mathrm{I})$-peptide complexes, presumably due to the ionization process. The electrons in the MALDI plume seem to efficiently reduce $\mathrm{Au}(\mathrm{III})$ to $\mathrm{Au}(\mathrm{I})$. MALDI also tends to enhance the higher polymeric forms of gold-peptide complexes regardless of the laser power used. Collision-induced dissociation experiments of the mononuclear and dinuclear gold-attached peptide ions for angiotensin peptides show that the gold ion (a soft acid) binding sites are in the vicinity of Cys (a soft ligand), His (a major anchor of peptide for metal ion chelation), and the basic residue Arg. Data also suggests that the abundance of gold-attached peptides increases with higher gold concentration until saturation, after which an increase in gold ion concentration leads to the aggregation and/or precipitation of gold-bound peptides.
\end{abstract}

Key words: Mass spectrometry, MS/MS, Gold ion, Peptide

\section{Introduction}

Cisplatin is a platinum(II) containing chemotherapy drug proven to be an effective treatment for several types of solid tumors [1-3]. However, a large number of cancer patients develop cisplatin resistance and a number of side effects are commonly reported [1-3]. For this reason, considerable efforts

Electronic supplementary material The online version of this article (doi:10.1007/s13361-011-0328-0) contains supplementary material, which is available to authorized users.

Correspondence to: Bao-Shiang Lee; e-mail: boblee@uic.edu have been made to create new effective anticancer metallodrugs [4-7]. Since gold(III) ion is isoelec-tronic with platinum(II) ion and it forms square-planar complexes as in cisplatin, gold(III) compounds are explored for potential anticancer activities. A number of gold(III) complexes with ligands such as bipyridyls, dithiocarbamato, porphyrins, and quinolines, which display in vitro and in vivo potent anticancer activities and reduced systemic toxicity compared with the cisplatin, have been synthesized [4-17]. Small peptides such as S-phenylalanine-S-phenylalanine, glycyl-alaline, glycylhistidine, alanyl-phenylalanine, glycyl-S-serine, glycyl-alanylalanine, glycyl-glycyl-histidine, and glycyl-glycyl-methyonylglycyl-glycine are another class of ligands of gold(III) ion that have been investigated for development of potential anticancer drugs [18-24]. Although evidence [10, 11, 28] suggests that gold-based chemotherapy agents seem to induce 


\section{J. Lee et al.: Gold Ion-Peptide Interaction}

antiproliferative activities against tumor cells, the main biological targets and mechanisms responsible for gold-induced cytotoxicity are still largely unknown. However, the interactions between gold-based chemotherapy agents and proteins are believed to be involved in the antitumor activity $[10,11,28]$. Detailed information on the interaction between gold ions and peptides/proteins is needed to shed light on the mechanism of gold compounds' anticancer activity and side effects and facilitate the design of gold-based anticancer agents.

With the development of gentle ionization techniques such as ESI [29, 30] and MALDI [31, 32] for transferring peptides/proteins into the gas phase without detrimental effects on their integrity, mass spectrometry has been used successfully to characterize metal cation (such as calcium, cadmium, cobalt, copper, iron, magnesium, mercury, nickel, potassium, sodium, and zinc) peptide/protein interactions [3346]. Data reveals some general findings such as various metal ions may interact differently to a peptide sequence [33, 47], and the metal cation-peptide/protein bond is believed to be noncovalent [33]. Many MS studies suggest that the $\mathrm{Cu}$-peptide ions by MALDI is formed by a reductive process which produces primarily $\mathrm{Cu}(\mathrm{I})$-peptide ions, whereas ESI process yields almost exclusively $\mathrm{Cu}(\mathrm{II})$-peptide ions unless a solvable copper emitter is used [34]. Collision induced dissociation (CID), a well established tandem mass spectrometry experiment, which produces the information of the sequence and metal ion binding sites of a peptide, of $\mathrm{Zn}$ ion- and $\mathrm{Cu}$ ion-angiotensin peptide complexes [34, 41, 48] indicate that zinc and copper interaction sites are in the neighborhood of the His and Arg residues, respectively. In addition, there are some MS studies on the gold-protein complexes [14, 28, 33, 49-52], disulfide bridge cleavage of gold(I) cationized peptides [53, 54], and characterization of synthetic pure gold-peptide complexes [21-27]. Data from gold-attached glutathione reductase or thioredoxin reductase probed by MALDI-TOF MS speculates that Cys residue is critical to their biological functions [14, 50]. However, X-ray crystal together with the ESI-MS studies show that the His residue of the enzyme cyclophilin is the gold ion binding site, despite the presence of four Cys thiol groups in the enzyme [54]. Results from gold bound human serum albumin and poly(ADP-ribose) polymerase by ESI-MS speculate that both Cys and His residues are involved in the gold ion binding [28, 51]. ESI-MS study on the $\mathrm{Au}(\mathrm{I})$-somatostin complex shows that $\mathrm{Au}(\mathrm{I})$ incorporation into a disulfide bridge containing peptide is a promising way to effect selective dissociation of disulfide bonds [52]. In another study, ESI-MS is used to confirm the reaction product of a synthetic $\mathrm{Au}(\mathrm{III})$-pentapeptide (GGMGG) complex [21]. The majority of these gold complex studies are all aimed at the binding between gold and sulfur. Clearly, systematic MS studies on simple Au-peptide complexes are needed to provide a basis for the another study,
ESI-MS is used to confirm the reaction product of a synthetic $\mathrm{Au}(\mathrm{III})$-pentapeptide (GGMGG) complex [21]. The majority of these gold complex studies are all aimed at the binding between gold and sulfur. Clearly, systematic MS studies on simple $\mathrm{Au}$-peptide complexes are needed to provide a basis for the interpretation of the interaction between gold ion and peptide/protein. As a first step of our gold ion-peptide/protein complex investigation, gold complexes of human angiotensin I (Asp-Arg-Val-Tyr-Ile-His-Pro-Phe-His-Leu), human angiotensin II (Asp-Arg-Val-Tyr-Ile-His-Pro-Phe), CysAngiotensin II (Cys-Asp-Arg-Val-Tyr-Ile-His-Pro-Phe), human angiotensin IV (Val-Tyr-Ile-His-Pro-Phe), VYIHPFHL (Val-Tyr-Ile-HisPro-Phe-His-Leu), tripeptide CDR, and dipeptide DR are probed by both ESI and MALDI-TOF/TOF MS. These choices enable the evaluation of the interaction between gold ion and potential metal binding amino acid residues. In addition, due to peptides' smaller sizes, data analysis is much simpler. Furthermore, besides angiotensin availability, its interactions with other metals investigated by MS have been reported, which enable the direct comparison between gold ion and other metal interactions with angiotensin peptides. Note that angiotensin II is a peptide hormone that causes hypertension and has been shown to inhibit proliferation of several cell types. Results obtained here show that singly/multiply charged ions for the mononuclear and/or dinuclear gold-attached peptide are detected in each complex. More abundant formation of gold ion-angiotensin complexes are detected as compare to the complex formation of $\mathrm{Zn}$ ion and $\mathrm{Cu}$ ion. In addition, CID data reveals many possible gold ion binding sites in the vicinity of Cys, His, and Arg of peptides, which is somewhat different from $\mathrm{Zn}$ ion (His is the preferred anchoring site) [48] and $\mathrm{Cu}$ ion (Arg is the preferred anchoring) [34, 41].

\section{Experimental}

\section{Chemicals and Materials}

All chemicals and peptides were purchased from SigmaAldrich Chemical Company (Saint Louis, MO, USA) and used without further purification. Peptides DR, CDR, and CDRVYIHPF (CysAngiotensin II) were synthesized inhouse by solid phase peptide synthesis (see Supplemental Material). Sequencing grade modified trypsin was obtained from Promega Corporation (Madison, WI, USA).

\section{Preparation of the Gold Ion-Peptide Complexes}

Gold ion-peptide complexes were prepared by mixing $2 \mathrm{mM}$ aqueous solution of $\mathrm{AuCl}_{3}$ or $\mathrm{AuCl}$ with an equimolar amount of peptide at room temperature. Concentration of gold ion greater than $\sim 10 \mathrm{mM}$ tends to encourage the precipitation of angiotensin I. Gold ion-angiotensin IV and VYIHPF were 


\section{J. Lee et al.: Gold Ion-Peptide Interaction}

prepared by trypsin digestion of gold-angiotensin I and II, respectively (see Supplementary Material).

\section{Analysis of the Gold Ion-Peptide Complex by Mass Spectrometry}

Gold ion-peptide samples for MALDI-TOF and MALDITOF/TOF MS analyses were prepared by either mixing equal amount of gold ion-peptide solution with matrix solution (3-10 mg Cyano-4-hydroxycinnamic acid in $1 \mathrm{ml}$ aqueous solution of $50 \%$ acetonitrile containing $0.1 \%$ TFA) or concentrating the gold ion-peptide complex with Millipore (Billerica, MA, USA) C18 ZipTips and then eluted with matrix solution. Applied Biosystems (Foster City, CA, USA) Voyager-DE PRO MALDI-TOF or 4700 Proteomics Analyzer MALDI-TOF/TOF MS equipped with a $337 \mathrm{~nm}$ pulsed nitrogen laser was used to analyze the samples. The mass spectrum was obtained using the delayed extraction positiveion linear and/or reflector modes by averaging 100 laser shots. Tandem MS (MALDI-TOF/TOF) experiments were conducted using collision energy of $1 \mathrm{kV}$ with helium as the collision gas. External mass calibration was performed using the masses of a mixture of bradykinin fragments $1-7$ at $\mathrm{m} / \mathrm{z} 757.40$, angiotensin II (human) at $m / z$ 1046.54, P14R (synthetic peptide) at $\mathrm{m} / \mathrm{z}$ 1533.86, and adrenocorticotropic hormone fragment 18-39 (human) at $m / z 2465.20$. Data explorer software and MS data analysis tools from Protein-Prospector (http://prospector.ucsf. edu/prospector/mshome.htm) or proteomicsToolkit (http://db. systemsbiology.net:8080/proteomics-Toolkit) were used to analyze the data.

For ESI-MS analysis, mass spectra were obtained using either a Thermo Electron (Waltham, MA, USA) LCQ-deca quadrupole ion trap mass spectrometer or LTQ FT ultra hybrid linear ion trap Fourier transform-ion cyclotron resonance (FTICR) mass spectrometer in the electrospray positive mode. A mass accuracy of $1 \mathrm{ppm}$ of the precursor ions is obtained with FT-MS. Sample was introduced into LCQ-deca quadrupole ion trap by direct infusion using a syringe pump with flow rate of $10 \mu \mathrm{L} / \mathrm{min}$. The FT-MS spectra were obtained by electrospray using a New Objective (Waltham, MA, USA) $4 \mu \mathrm{m}$ glass tip static probe with standard coating at a flow rate of $40-100$ $\mathrm{nL} / \mathrm{min}$.

For HPLC-ESI-MS gold ion-peptide analysis, sample is injected onto an Agilent (Santa Clara, CA, USA) $2.1 \mathrm{~mm} \mathrm{SB}-$ C18 or $75 \mu \mathrm{m}$ Zorbax SB300 C-18 reversed-phase column connected to a Dionex (Sunnyvale, CA, USA) Ultimate 3000 HPLC system. The samples were separated using a binary solvent system consisting of A: $0.1 \%$ formic acid and 5\% acetonitrile and B: $0.1 \%$ formic acid and $95 \%$ acetonitrile at flow rate of $200 \mu \mathrm{L} / \mathrm{min}$ or $200 \mathrm{~nL} / \mathrm{min}$. A gradient was run from 5\% B to $60 \% \mathrm{~B}$ over 30 or $60 \mathrm{~min}$. The mass spectrometer was operated in positive ion mode with the trap set to data dependent MS/MS acquisition mode. Peaks eluted from the LC column that had ions above 1000 arbitrary intensity units trigger the ion trap to isolate the ion and perform an MS/MS experiment scan after the MS full scan. The ICR cell was run with a resolution setting of 100,000 at $\mathrm{m} / \mathrm{z} 400$ over the range from $\mathrm{m} / \mathrm{z} 200$ to 2000 . The MS was operated under the following conditions: capillary temperature $200{ }^{\circ} \mathrm{C}$; sheath gas 2 psi and spray voltage $2.0 \mathrm{kV}$. The Xcalibur software was used to analyze the data.

\section{Results and Discussion}

\section{Au Ion-Angiotensin I Complexes}

MALDI-TOF MS (Figure 1) of the angiotensin I in reaction with $1 \mathrm{mM}$ gold ion shows predominately singly charged intact $\left(\mathrm{m} / \mathrm{z}\right.$ 1296.68; abundant), singly gold-attached $[\mathrm{M}+\mathrm{Au}(\mathrm{I})]^{+}(\mathrm{m} / \mathrm{z}$ 1492.65; most abundant), and doubly gold-attached [M+2Au(I) $-\mathrm{H}]^{+}(\mathrm{m} / z$ 1688.62; less abundant) angiotensin I ions. Results are identical no matter which gold ion is used (either $\mathrm{AuCl}_{3}$ or $\mathrm{AuCl})$. This observation in MALDI-TOF MS suggests that MALDI process suppresses the detection of oxidation state III and encourages the reduction of $\mathrm{Au}(\mathrm{III})$ to $\mathrm{Au}(\mathrm{I})$ by electrons in the MALDI plume [55]. Similar findings have been reported for $\mathrm{Cu}$ ion-peptide complexes [34]. Since Gold has only one stable naturally occurring isotope ${ }^{197} \mathrm{Au}$ with atomic mass 196.96654 , the interpretation of the mass spectrum is relatively simpler. The formula that describes the stoichiometry of the singly charged gold-peptide complex detected by MALDI-TOF MS is given by $[\mathrm{M}+\mathrm{a} \mathrm{Au}(\mathrm{I})+(1-\mathrm{a}) \mathrm{H}]^{+}$, where $\mathrm{a}=1,2 . \mathrm{HCl}$ adduct [54] of singly gold-attached $(\mathrm{m} / \mathrm{z}, 1528.65)$ and doubly gold-attached $(\mathrm{m} / z$ 1724.62) angiotensin I ions are also detected. In addition higher polymeric forms of goldangiotensin I complex (i.e., $[\mathrm{aM}+\mathrm{bAu}(\mathrm{I})+(\mathrm{b}-1) \mathrm{H}]^{+}$, where a,b $\geq 1)$, such as $[2 \mathrm{M}+\mathrm{Au}(\mathrm{I})]^{+}$at $\mathrm{m} / z, 2790.33$ and $[2 \mathrm{M}-$ $3 \mathrm{H}+4 \mathrm{Au}(\mathrm{I})]^{+}$at $m / z 3376.24$, are also detected with much lower intensities regardless of the laser power used. This result is consistent with the property of gold which has a tendency to form supramolecular architecture (aurophilicity) due to its unusually large relativistic 6 s-orbital stabilization (contraction) [56]. In addition, this observation is similar to the results of $\mathrm{Cu}$ ion-peptide complexes [34], which reports the detection of [peptide $+\mathrm{xCu}-(\mathrm{x}-1) \mathrm{H}](\mathrm{x}=1-6)$ ions. Here, multiply charged ions are rarely detected due to the MALDI set-up (normal MALDI instead of laserspray ionization MALDI) that was used [57, 58]. Interestingly, doubly charged ion $(\mathrm{m} / \mathrm{z}, 746.83)$ of singly gold-attached angiotensin $\mathrm{I}(\mathrm{m} / \mathrm{z}, 1492.65)$ is detected 


\section{J. Lee et al.: Gold Ion-Peptide Interaction}

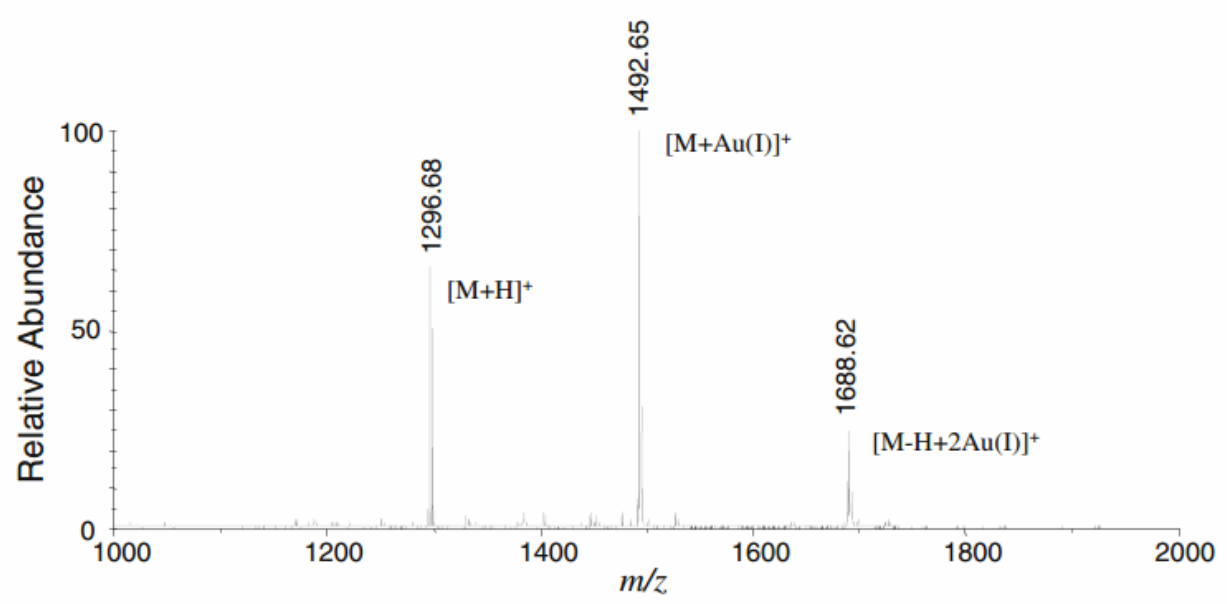

Figure 1. MALDI-TOF of Angiotensin I in the presence of $1 \mathrm{mM} \mathrm{AuCl}_{3}$. The matrix used for desorption is cyano-4hydroxycinnamic acid

with lower intensity. The relative abundance of the goldattached angiotensin I ion species compared with the intact ion depends on the concentration of the gold ion. It is directly proportional to the concentration of $\mathrm{AuCl}_{3} / \mathrm{AuCl}$, becoming undetectable when the concentration of gold ion is lower than $0.5 \mu \mathrm{M}$. However, at concentration of $\mathrm{AuCl}_{3}$ higher than 10 $\mathrm{mM}$, the solution turns cloudy. The MS signals become undetectable when the concentration of $\mathrm{AuCl}_{3}$ is higher than $250 \mathrm{mM}$, indicating that the gold-bounded species aggregate or precipitate out of the solution.

ESI-MS (Figure 2, only relevant ions are shown) of the angiotensin $\mathrm{I}$ in reaction with $1 \mathrm{mM} \mathrm{AuCl} \mathrm{Al}_{3}$ shows predominately three kinds of ion species. (1) Intact angiotensin I ions (singly charged, $m / z$ 1296.68; doubly charged $m / z$ 648.84; triply charged, $m / z$ 432.89). (2) Singly gold-attached angiotensin I ions $[\mathrm{M}+\mathrm{Au}(\mathrm{I})+(\mathrm{e}-1) \mathrm{H}]^{\mathrm{e}+}$ (singly charged, $\mathrm{m} / z$ 1492.65; doubly charged, $m / z$ 746.83; triply charged, $m / z$ 498.22) and $[\mathrm{M}+\mathrm{Au}(\mathrm{III})+(\mathrm{e}-3) \mathrm{H}]^{\mathrm{e}+}$ (singly charged, $\mathrm{m} / z$ 1490.65; doubly charged, $m / z$ 745.82; triply charged, $m / z$ 497.55). (3) Doubly gold-attached angiotensin I ions $[\mathrm{M}+2 \mathrm{Au}(\mathrm{I})+(\mathrm{e}-2) \mathrm{H}]^{\mathrm{e}+}$ (singly charged, $\mathrm{m} / \mathrm{z}$ 1688.62; doubly charged, $\mathrm{m} / \mathrm{z}$ 844.81; triply charged, $m / z$ 563.54), $[\mathrm{M}+\mathrm{Au}(\mathrm{I})+\mathrm{Au}(\mathrm{III})+(\mathrm{e}-4) \mathrm{H}]^{\mathrm{e}+}$ (singly charged, $\mathrm{m} / \mathrm{z}$ 1686.62; doubly charged, $\mathrm{m} / \mathrm{z}$ 843.81; triply charged, $m / z$ 562.87), and $[\mathrm{M}+\mathrm{Au}(\mathrm{III})+\mathrm{Au}(\mathrm{III})+(\mathrm{e}-6)$ $\mathrm{H}]^{\mathrm{e}+}$ (singly charged, $\mathrm{m} / \mathrm{z}$ 1684.62; doubly charged, $\mathrm{m} / \mathrm{z}$ 842.81; triply charged, $m / z$ 562.21). Data shows the gold ions exist in oxidation states of III and I, indicating some reduction of $\mathrm{Au}(\mathrm{III})$ to $\mathrm{Au}(\mathrm{I})$. Also shown are $\mathrm{HCl}$ adduct of singly goldattached and doubly gold-attached angiotensin I ions and higher polymeric forms of gold-angiotensin I complexes (i.e., $\left.[\mathrm{aM}+\mathrm{bAu}(\mathrm{I})+\mathrm{cAu}(\mathrm{III})+(\mathrm{e}-\mathrm{b}-3 \mathrm{c}) \mathrm{H}]^{\mathrm{e}+}\right)$, such as $[2 \mathrm{M}+\mathrm{Au}(\mathrm{III})]^{3+}$ at $m / z, 929.44$ and $[2 \mathrm{M}+2 \mathrm{Au}(\mathrm{I}, \mathrm{III})-\mathrm{H}]^{3+}$ at $m / z$ 944.76. Higher polymeric forms of gold-angiotensin I complexes are present at lower amount by ESI-MS than by MALDI-TOF MS. The relationship between relative abundance of the gold-attached ion species and concentration of $\mathrm{AuCl}_{3}$ is similar as in MALDITOF MS data described above. However, concentrations of gold ion higher that $10 \mathrm{mM}$ greatly suppress the ESI-MS signal.

ESI-MS (Figure 3, only relevant ions are shown) of the angiotensin $\mathrm{I}$ in reaction with $1 \mathrm{mM} \mathrm{AuCl}$ shows three major kinds of ion species. (1) Intact angiotensin I ions described in the previous paragraph. (2) Singly gold-attached angiotensin I ions $[\mathrm{M}+\mathrm{Au}(\mathrm{I})+(\mathrm{e}-1) \mathrm{H}]^{\mathrm{e}+}$ (singly charged, $\mathrm{m} / \mathrm{z}$ 1492.65; doubly charged, $m / z$ 746.83; triply charged, $m / z$ 498.22). (3) Doubly gold-attached angiotensin I ions $[\mathrm{M}+2 \mathrm{Au}(\mathrm{I})+(\mathrm{e}-2)$ $\mathrm{H}^{\mathrm{e}+}$ (singly charged, $\mathrm{m} / \mathrm{z}, 1688.62$; doubly charged, $\mathrm{m} / \mathrm{z}$ 844.81) and $[\mathrm{M}+\mathrm{Au}(\mathrm{I})+\mathrm{Au}(\mathrm{III})+(\mathrm{e}-4) \mathrm{H}]^{\mathrm{e}+}$ (singly charged, $\mathrm{m} / \mathrm{z}$ 1686.62; doubly charged, $\mathrm{m} / \mathrm{z}$ 843.80). The gold ion exists predominately in oxidation state of I. The detection of doubly gold-attached angiotensin $\mathrm{I}[\mathrm{M}+\mathrm{Au}(\mathrm{I})+\mathrm{Au}(\mathrm{III})+(\mathrm{e}-4) \mathrm{H}]^{\mathrm{e}+}$ indicates that some of the $\mathrm{Au}(\mathrm{I})$ disproportionate in aqueous solution to $\mathrm{Au}(\mathrm{III})$. The $\mathrm{HCl}$ adduct of gold-attached angiotensin I complexes described in the previous paragraph are also observed. The relationship between relative abundance of the gold-attached ion species and concentration of $\mathrm{AuCl}$ is similar as in MALDI-TOF MS described above.

The fact that only gold ion in the oxidation state $\mathrm{I}$ is observed in MALDI-TOF MS indicates that MALDI process suppresses the detection and promotes the reduction of higher oxidation states. Additionally, due to the difference in the ionization process between MALDI (addition of matrix, drying of the sample, and desorption by a laser) and ESI, the former tends to encourage the detection of higher polymeric forms of gold-peptide complexes. The CID data of singly and multiply charged angiotensin I and gold-bound angiotensin I by MALDI-TOF/TOF (Figure 4) and ESI-MS/MS (see Figure S1 in Supplementary Material) reveals detailed information regarding the binding between gold ion and angiotensin I. The nomenclature for CID fragment ions, chemical structure, and 


\section{J. Lee et al.: Gold Ion-Peptide Interaction}

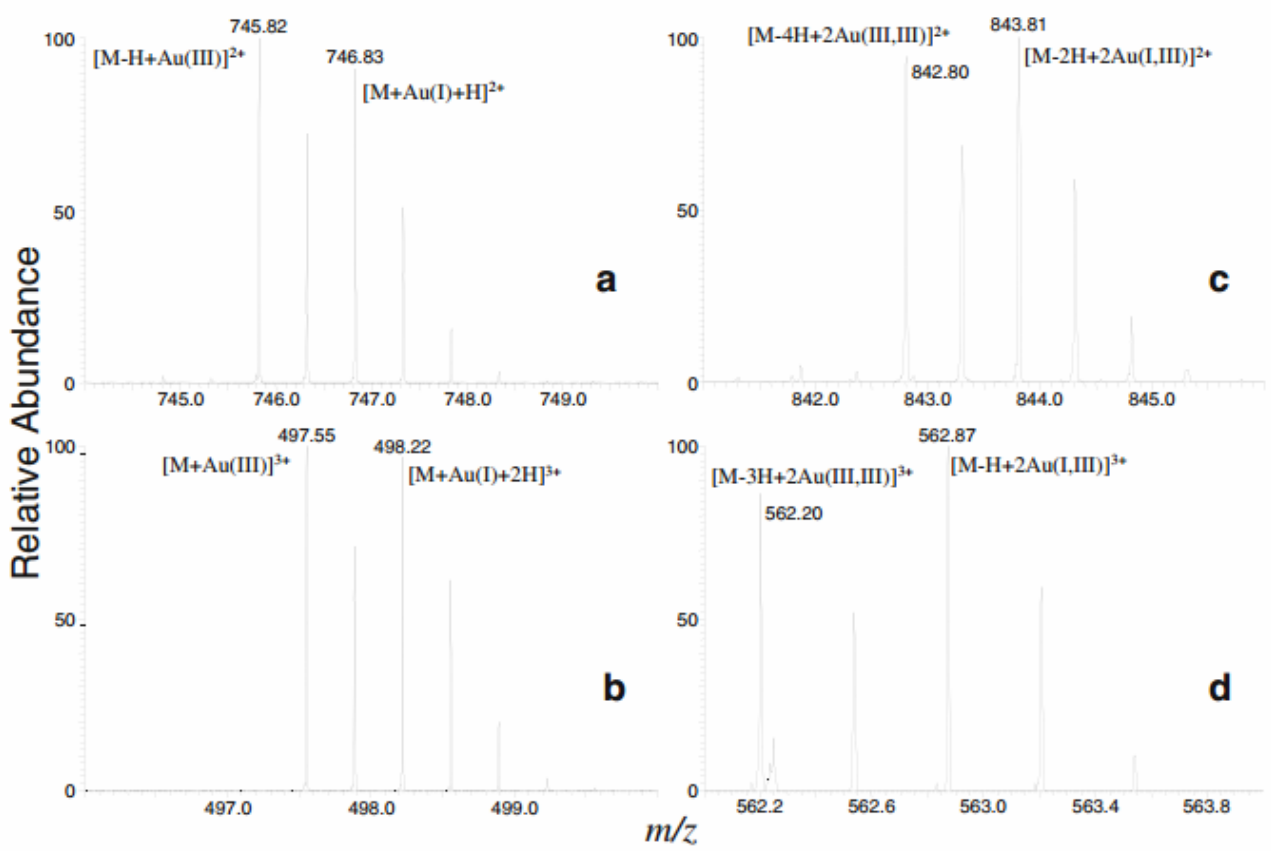

Figure 2. The ESI-MS of angiotensin I in the presence of $1 \mathrm{mMAuCl}_{3}$. Expanded regions of peaks corresponding to (a) $[\mathrm{M}+\mathrm{Au}]^{2+}$, (b) $[\mathrm{M}+\mathrm{Au}]^{3+}$, (c) $[\mathrm{M}+2 \mathrm{Au}]^{2+}$, and (d) $[\mathrm{M}+2 \mathrm{Au}]^{3+}$ ions

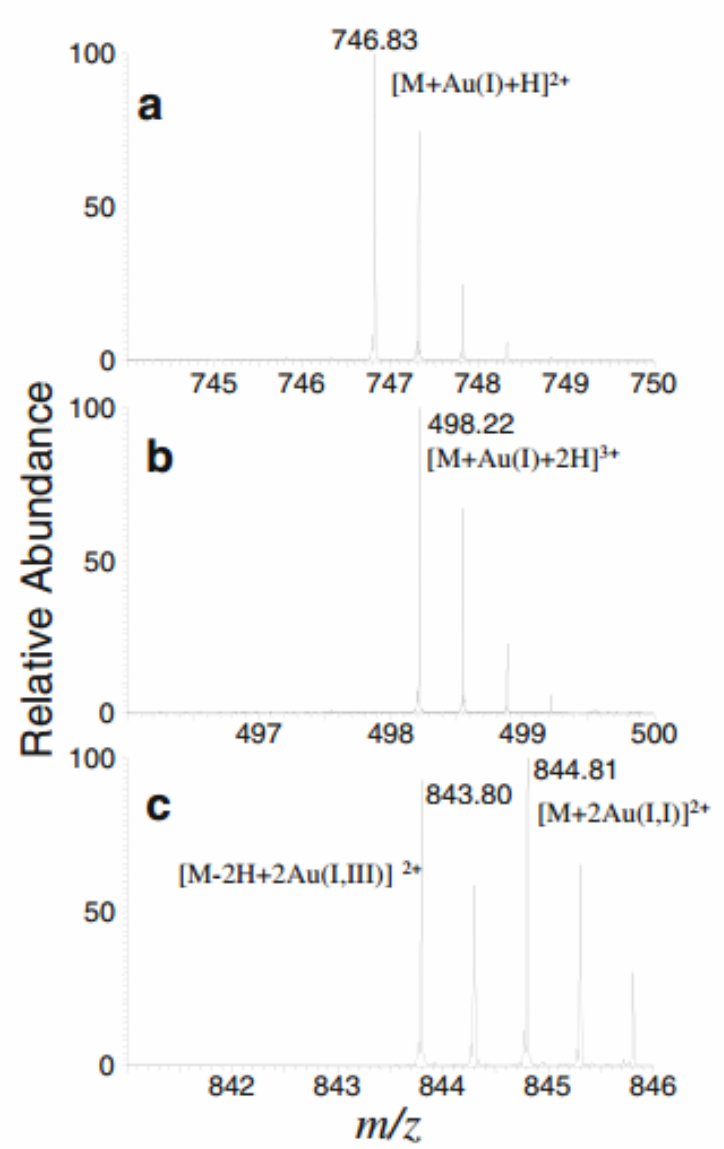

Figure 3. The ESI-MS of angiotensin I in the presnece of $1 \mathrm{mM}$ $\mathrm{AuCl}$. Expanded regions corresponding to $(\mathrm{a})[\mathrm{M}+\mathrm{Au}]^{2+}$, (b) $[\mathrm{M}+\mathrm{Au}]^{3+}$, and (c) $[\mathrm{M}+2 \mathrm{Au}]^{2+}$ ions peptide sequence of angiotensin I can be found in Supplementary Material. Three major types of backbone bonds may be broken upon CID, leading to six homologous series of fragment ions ( $a, b, c, x, y$, and $\mathrm{z}$ ions) [59-61]. The a-type, $\mathrm{b}$ type, and c-type fragment ions contain the $\mathrm{N}$-terminus $(\mathrm{N}$ terminal fragment ions), whereas $\mathrm{x}$-type, $\mathrm{y}$-type, and $\mathrm{z}$-type fragment ions contain the $\mathrm{C}$-terminus (C-terminal fragment ions). Numerical subscripts indicate the position of the amino acid residues at the cleavage sites. Both ionization methods produce strong signals from $\mathrm{b}, \mathrm{y}$, and a ion series in addition to the ions formed by $\mathrm{H}_{2} \mathrm{O}, \mathrm{NH}_{3}$, or $\mathrm{CO}$ loss. Several factors contribute to the efficacy of the identification of gold binding sites using the CID mass spectra. First, due to the large relativistic effect of gold [56], gold-peptide binding is relatively strong and survive the CID condition used here. Second, angiotensin I contains one Arg and two His basic residues equally distributed along the peptide chain, one Pro residue in the middle of the peptide chain, and one Asp residue. Note that peptide fragments containing basic residues (protonated preferentially and retain the charge) tend to dominate the CID mass spectrum, and the Pro residue in the peptide sequence tends to enhance the cleavage of the peptide bond n-terminal to it due to a higher basicity of the imide nitrogen. Additionally, cleavage at the c-terminus of Asp residue is favored because of protonation of the peptide bond by the Asp side-chain carboxyl group. The majority of the a, b, and $\mathrm{y}$ series are detected in this study, which facilitate the identification of the gold binding sites. Third, angiotensin I is a short peptide with 10 amino acid residues, which makes the 


\section{J. Lee et al.: Gold Ion-Peptide Interaction}

data interpretation relatively easy. The immonium ions (a singly side chain fragment formed by a combination of a-type and y-type cleavage) detected in MALDI-TOF/TOF unambiguously identified the presence of $\operatorname{Arg}(\mathrm{m} / \mathrm{z}, 87,100$, and 112), Asp ( $m / z, 88)$, Ile/Leu $(m / z, 86)$, His $(m / z 110$ and 138), Phe $(\mathrm{m} / \mathrm{z} 120)$, Pro $(\mathrm{m} / \mathrm{z}$ 70), Tyr $(\mathrm{m} / \mathrm{z} 136)$, and Val $(\mathrm{m} / \mathrm{z} 72)$. Since the peptide contains Pro amino acid residue, enhanced signals from internal ions (double backbone cleavage of $b$ type and y type; contain neither N-terminus nor C-terminus) and $\mathrm{Y}$ (y-2)-type ions are also detected. An abundant $\mathrm{y}_{9}$ ion at $\mathrm{m} / \mathrm{z}$ 1377 is detected, which corresponds to a $115 \mathrm{Da}$ loss from the molecular ion. Considering the correlation between complementary $\mathrm{b}$ and $\mathrm{y}$ ions $\left(\mathrm{y}_{\mathrm{i}}+\mathrm{b}_{10-\mathrm{i}}-1=\mathrm{MH}^{+}\right)$, this mass difference is consistent with $a b_{1}$ mass of $116 \mathrm{Da}$ (Asp as the N-terminus). CID data shows that the singly gold-attached angiotensin I consists of three species. One species has the gold bonded to the basic residue Arg (e.g., $b_{2}, b_{4}$, and $b_{5}$ ions in Figure 4a). The significance of the Arg residue in peptide-metal bonding has been reported on Arg containing peptide-metal ion interactions [41, 47]. The basic guanidinium group ( $\mathrm{pKa}$ of 12.48) of Arg and the conjugation between double bond and the nitrogen lone pairs most likely contribute to the binding between Arg and gold ion (soft acid). To further confirm the importance of the Arg residue in peptide-gold bonding, dipeptide DR is synthesized and its gold complex is probed by MS (see Figure S2 in Supplementary Material). Since there is only one gold binding site in DR (Arg at position 2), as expected, the CID data of the gold ion-dipeptide DR complex shows that the gold binding site is Arg and not the $\mathrm{NH}_{2}$ terminal amino group or Asp. The other two species have the gold anchored at His residue at the sixth position (e.g., VYIH(Au), YIH(Au)P internal ions in Figure4a) or ninth position (e.g., $b_{7}$ and $b_{8}$ ions in Figure S1b in Supplementary Material), most likely through the N3 site of the His-imidazole ring (the major metal anchoring site beside sulfur of Cys) [21, 26, 52, 62, 63]. Similar conclusions indicate that both His residues are involved in the metal binding has been reported on Zn-angiotensin I complexes [48]. Doubly gold-attached angiotensin I also shows three species [gold bonded through Arg and His at position 6 (e.g., $\mathrm{a}_{8}$, and $\mathrm{y}_{8}$ ions in Figure 4b), gold bonded through the Arg and His at position 9 (e.g., $\mathrm{y}_{5}$ ion in Figure 4b), and gold bonded through both His at positions 6 and 9 (e.g., $\mathrm{y}_{5}, \mathrm{y}_{6}, \mathrm{y}_{7}$, and $\mathrm{y}_{8}$ ions in Figure 4b)]. Note that bidentate and/or tridentate coordination of gold ion by the Arg and two His residues is also possible structures from these results. The bidentate/tridentate complexes have been proposed to be the possible structures in previous studies on $\mathrm{Cu}$ - and $\mathrm{Zn}$ angiotensin complexes [34, 48]. In addition, many NMR and $\mathrm{X}$-ray studies on simple Au-peptide complexes have proposed multidentate structures involving the amide nitrogen and the $\mathrm{N}$ terminal $\mathrm{NH}_{2}$ group in addition to the amino acid residues [2127].

The angiotensin I solution containing gold ion is digested with trypsin to produce gold ion-VYIHPFHL complex.

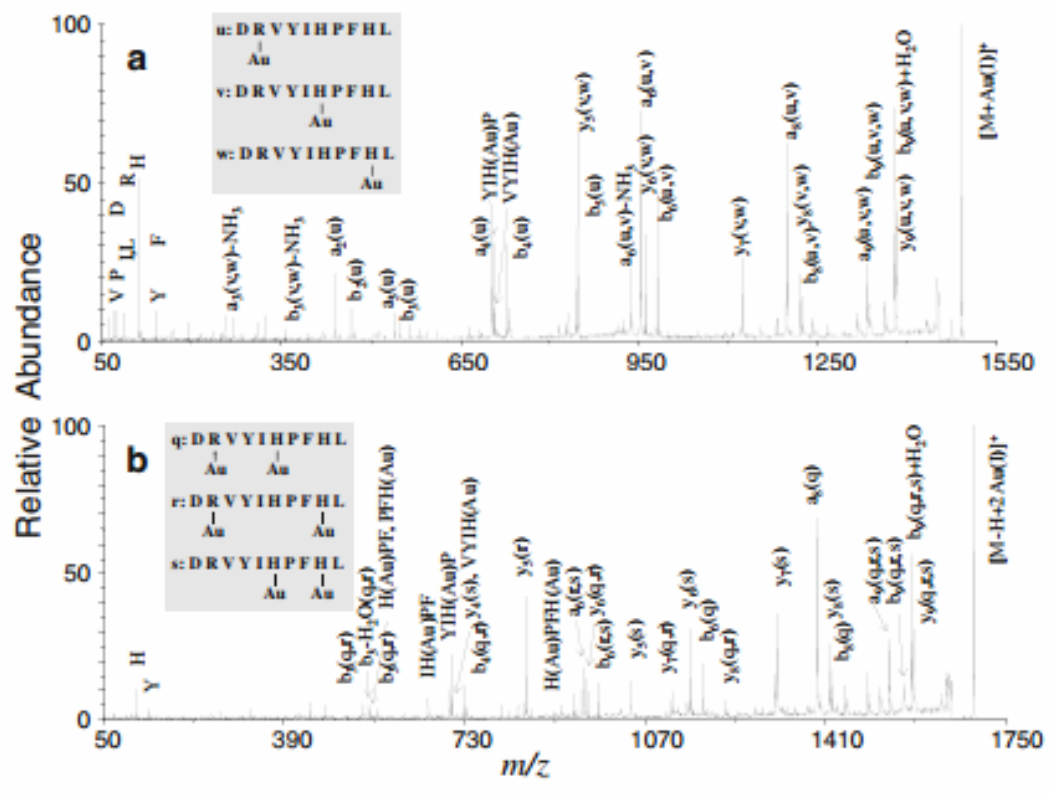

Figure 4. CID mass spectra (MALDI-TOF/TOF) of (a) $[\mathrm{M}+\mathrm{Au}(\mathrm{I})]^{+}$and (b) $[\mathrm{M}-\mathrm{H}+2 \mathrm{Au}(\mathrm{I})]^{+}$ions of angiotensin I 


\section{J. Lee et al.: Gold Ion-Peptide Interaction}

MALDI-TOF MS and CID mass spectra (MALDI-TOF/TOF MS) of intact and singly gold-attached VYIHPFHL are shown in Figure S3 in Supplementary Material. Since there are two gold binding sites in VYIHPFHL (His at positions 4 and 7), as expected, the data is in agreement with a mixture of two gold ion-VYIHPFHL species [gold bonded through the $\mathrm{His}$ at position 6 (e.g., $\mathrm{y}_{2}, \mathrm{a}_{4}, \mathrm{~b}_{4}$, and $\mathrm{b}_{6}$ ions in Figure $\mathrm{S} 3 \mathrm{c}$ in Supplementary Material) and 7 (e.g., $\mathrm{y}_{3}, \mathrm{a}_{5}$, and $\mathrm{b}_{5}$ ions in Figure S3c in Supplementary Material)]. Same evidence of the gold-VYIHPFHL interaction is provided in ESI-MS/MS CID mass spectra (see Figure S4 in Supplementary Material). Although preferential peptide bond cleavages near His, followed by $\mathrm{Au}$ attachment to the pieces, can also explain the observed fragmentation pattern, data here seems to rule out this possibility because there is no amino acid besides His that has a high metal affinity in both VYIHPFHL and VYIHPF (data presented below).

\section{Au Ion-Angiotensin II Complexes}

MALDI-TOF MS (Figure 5a) of the angiotensin II in reaction with either $1 \mathrm{mM} \mathrm{AuCl}$ or $\mathrm{AuCl}$ shows predominately singly charged intact ( $\mathrm{m} / \mathrm{z}$ 1046.54; abundant) and singly goldattached $[\mathrm{M}+\mathrm{Au}(\mathrm{I})]^{+}(\mathrm{m} / \mathrm{z}$ 1242.50; less abundant) angiotensin II ions. The doubly gold-attached angiotensin II is barely detected at $m / z$ 1438.47. The lower intensity for $m / z 1438.47$ may stem from one less His residue (a major metal anchor site of a peptide) compared with angiotensin I. This observation is somewhat different from the Zn-angiotensin II complex, which shows no difference in the relative ratio of singly $\mathrm{Zn}$-attached and doubly Zn-attached peptide between angiotensin I and angiotensin II [48]. ESI-MS (see Figure S5 in Supplementary Material) of the angiotensin II in reaction with either $1 \mathrm{mM}$ $\mathrm{AuCl}_{3}$ or $\mathrm{AuCl}$ shows predominately the intact (singly charged, $\mathrm{m} / \mathrm{z}$ 1046.54; doubly charged, $\mathrm{m} / \mathrm{z}$ 523.77; triply charged, $\mathrm{m} / \mathrm{z}$ $349.52)$, singly gold-attached $[\mathrm{M}+\mathrm{Au}(\mathrm{III})+(\mathrm{e}-3) \mathrm{H}]^{\mathrm{e}+}$ (singly charged, $m / z$ 1240.50; doubly charged, $m / z$ 620.75), and doubly gold-attached $[\mathrm{M}-\mathrm{H}+2 \mathrm{Au}(\mathrm{I}, \mathrm{III})]^{+}$(singly charged, $\mathrm{m} / \mathrm{z}$ 1436.47) angiotensin II. Interestingly, the gold ion exists predominately in oxidation state of III in ESI-MS for singly gold-attached angiotensin II no matter which gold ion is used. Angiotensin II in the ESI condition seems to stabilize the highly oxidative gold(III) and promotes the disproportion of $\mathrm{Au}(\mathrm{I})$ to $\mathrm{Au}(\mathrm{III})$. The relationship between relative abundance of the gold-attached ion species and concentration of $\mathrm{AuCl}_{3}$ or $\mathrm{AuCl}$ is similar as in angiotensin I described above.

The binding sites between gold and angiotensin II is revealed by CID mass spectra of singly and multiply charged singly gold-bound, and doubly gold-bound angiotensin II by MALDI-TOF/TOF (Figure 5b and c) or ESI- MS/MS (see Figure S6 in Supplementary Material). Since there is one less His residue in angiotensin II than angiotensin I, as expected, data shows that the singly gold-attached angiotensin II consists of two species. One species has the gold bonded through the $\operatorname{Arg}$ (e.g., $b_{2}, b_{4}$, and $b_{5}$ ions in Figure $5 b$ ) and the other has the gold bonded through His residue (e.g., $\mathrm{y}_{3}, \mathrm{y}_{4}$, and $\mathrm{y}_{5}$ ions in Figure $5 \mathrm{~b}$ ). Since the charge is retained near the N-terminus of the first species and C-terminus of the second species, the CID mass spectra is dominated by b-type and y-type fragment ions in the first and second species, respectively. Doubly goldattached angiotensin II consists of only one species with one gold chelated with Arg and the other with His (e.g., $b_{2}, y_{4}$, and $\mathrm{y}_{5}$ ions in Figure $5 \mathrm{c}$ ).

The reaction solution of gold ion and angiotensin II is digested with trypsin to produce gold ion-angiotensin IV (VYIHPF) complex. MALDI-TOF MS and CID mass spectra (MALDI-TOF/TOF) of intact and singly gold-attached Angiotensin IV are shown in Figure S7 in Supplementary Material. Since there is only one gold binding residue His in angiotensin IV, as expected, the data interpretation is much simpler and it is in agreement with the conclusion that His (e.g., $\mathrm{y}_{3}, \mathrm{a}_{4}$, and $\mathrm{y}_{5}$ ions in Figure S7c in Supplementary Material) is the gold ion binding site for gold ion-angiotensin IV complexes. ESI-MS/MS (see Figure S8 in Supplementary Material) CID data on singly and doubly charged intact and singly gold-attached angiotensin IV further confirms this conclusion. Interestingly, doubly gold-attached of neither VYIHPF or VYIHPFHL is detected in this study. Unlike angiotensin I and II situation described above, additional His residue in VYIHPFHL does not promote additional gold ion attachment.

\section{Au Ion-CysAngiotensin II Complexes}

Evidence indicates that sulfhydryl group of Cys is an important $\mathrm{Cu}^{2+}, \mathrm{Zn}^{2+}$, and $\mathrm{Hg}^{2+}$ anchoring site of peptides [43, 64, 65] and gold ion binding site of proteins [14, 28, 50, 51]. CysAngiotensin II (CDRVYIHPF) is synthesized and its interaction with gold ions is probed by MS. MALDI-TOF MS (Figure 6a) of the reaction solution containing CysAngiotensin II in $1 \mathrm{mM} \mathrm{AuCl} 3$ or $\mathrm{AuCl}$ showed predominately singly charged intact ( $\mathrm{m} / \mathrm{z}$ 1149.55; abundant), singly gold-attached $[\mathrm{M}+\mathrm{Au}(\mathrm{I})]^{+}(\mathrm{m} / \mathrm{z}$ 1345.52; less abundant), and doubly goldattached $[\mathrm{M}+2 \mathrm{Au}(\mathrm{I})]^{+}(\mathrm{m} / \mathrm{z}, 1541.48$; abundant $)$ CysAngiotensin II ions. Similar to the MALDI-TOF MS data, ESI-MS (see Figure S9 in Supplementary Material) shows predominately the intact (singly charged, $\mathrm{m} / \mathrm{z}$ 1149.55; doubly charged, $\mathrm{m} / \mathrm{z}$ $575.28)$, singly gold-attached $[\mathrm{M}+\mathrm{Au}(\mathrm{I})+(\mathrm{e}-1) \mathrm{H}]^{\mathrm{e}+}$ (singly charged, $m / z$ 1345.52.; doubly charged, $m / z$ 673.27), and doubly gold-attached $[\mathrm{M}+2 \mathrm{Au}(\mathrm{I})+(\mathrm{e}-2) \mathrm{H}]^{\mathrm{e}+}$ (singly charged, $m / z$ 1541.48; doubly charged, $m / z$ 771.24) angiotensin II ions. Interestingly, the gold ion exists predominately in oxidation 


\section{J. Lee et al.: Gold Ion-Peptide Interaction}
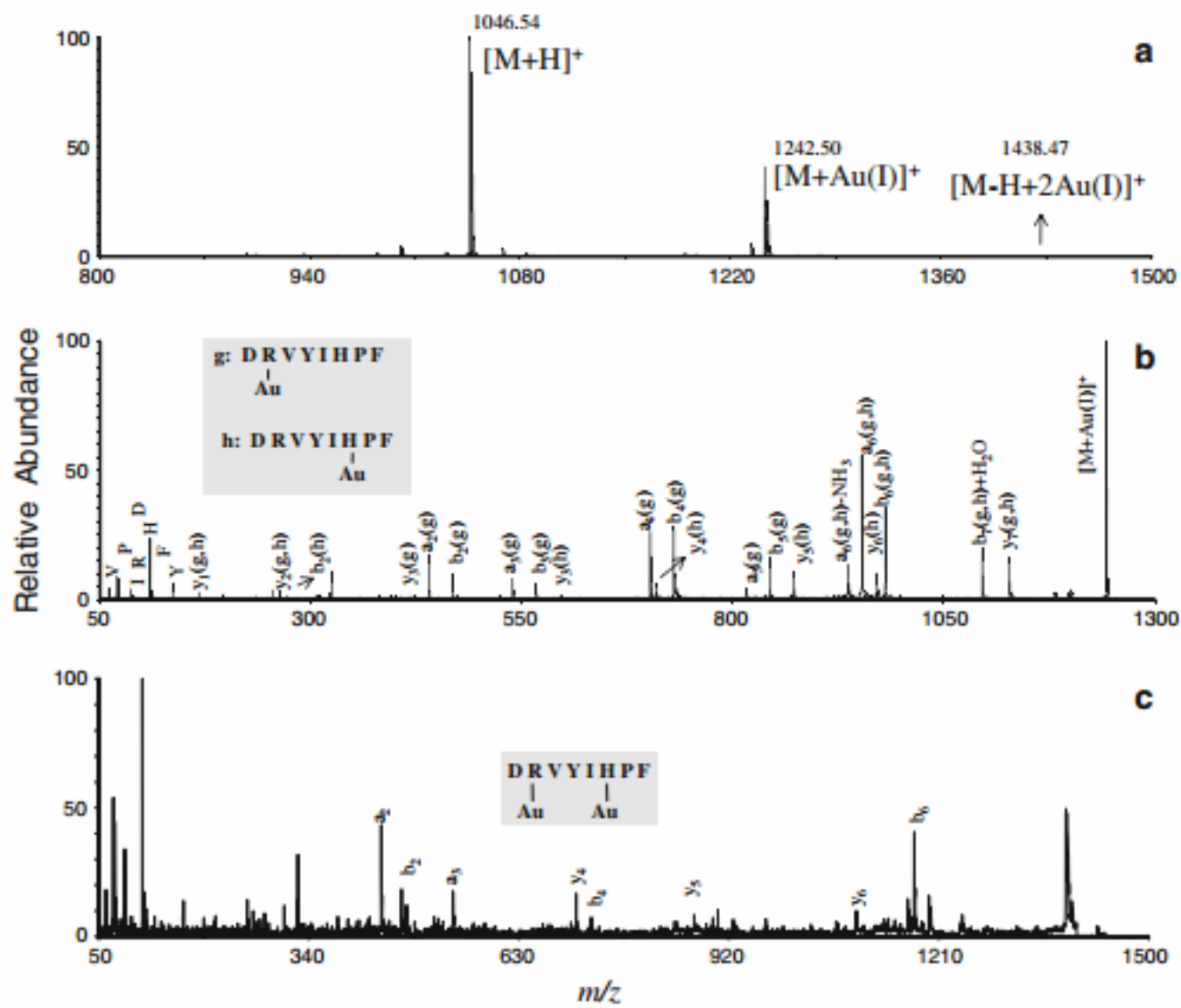

Figure 5. MS of angiotensin II in the presence of $1 \mathrm{mM} \mathrm{AuCl}_{3}$ : (a) MALDI-TOF MS; (b) CID mass spectrum (MALDI-TOF/TOF) of $[\mathrm{M}+\mathrm{Au}(\mathrm{I})]^{+}$; and (c) CID mass spectrum (MALDI-TOF/TOF) of $[\mathrm{M}-\mathrm{H}+2 \mathrm{Au}(\mathrm{I})]^{+}$

state of $+\mathrm{I}$ for gold-attached CysAngiotensin II with either $\mathrm{AuCl}_{3}$ or $\mathrm{AuCl}$. The ESI condition seems to stabilize the gold(I) and promote the reduction of $\mathrm{Au}(\mathrm{III})$ to $\mathrm{Au}(\mathrm{I})$ probably by oxidizing the sulfhydryl group of Cys. The oxidized products of Cys are clearly present in Figure 6a at $m / z, 1165.55$ (convert cysteine to the corresponding sulfenic acid), $\mathrm{m} / \mathrm{z}$ 1181.55 (convert cysteine to the corresponding sulfinic acid), and to a lesser extent $\mathrm{m} / \mathrm{z} 1197.55$ (convert cysteine to the corresponding sulfonic acid). The relationship between relative abundance of the gold-attached ion species and concentration of $\mathrm{AuCl}_{3}$ or $\mathrm{AuCl}$ is similar as in angiotensin I described above.

The gold anchoring sites are identified as Cys, Arg, and His by CID mass spectra of singly and multiply charged intact, singly gold-bound, and doubly gold-bound CysAngiotensin II (Figure $6 \mathrm{~b}-\mathrm{d}$ and Figure S10 in Supplementary Material). An additional immonium ion detected at $\mathrm{m} / \mathrm{z}$ 76, beside the immonium ions from Angiotensin II, in MALDI-TOF/TOF unambiguously identified the presence of Cys residue. As expected, data shows that the singly gold-attached CysAngiotensin II consists of three species. One species has the gold bonded through the residue Cys (e.g., $b_{2}$, RVYIH, and $\mathrm{y}_{7}$ ions in Figure 6c), most likely through the sulfur group, and the other two species have the gold bonded through the residue $\mathrm{Arg}$ (e.g., DR(Au)VY ion in Figure 6c) and residue His (e.g., $y_{3}, y_{5}$, and $y_{7}$ ions in Figure 6c), respectively. Data for the doubly gold-attached CysAngiotensin II also shows three species [gold bonded through both Cys and $\operatorname{Arg}$ (e.g., $b_{3}, y_{3}$, and $b_{5}$ ions in Figure 6d), gold bonded through both Cys and His (e.g., RVY ion in Figure 6d), and gold bonded through the $\mathrm{Arg}$ and His (e.g., $\mathrm{y}_{8}-\mathrm{H}_{2} \mathrm{O}$ ion in Figure 6d)]. ESI-MS/MS (see Figure S10 in Supplementary Material) CID data on singly and doubly charged intact, singly gold-attached, and doubly goldattached CysAngiotensin II further supports the conclusion. To further confirm the importance of the Cys in gold binding, CID (MALDI-TOF/TOF) mass spectra are obtained with a simple synthetic tripeptide CDR and its gold complex to facilitate the data interpretation. The CID data of the intact, singly goldbound $\left(\mathrm{y}_{1}, \mathrm{y}_{2}\right.$, and $\mathrm{a}_{3}$ ions in Figure S11 in Supplementary Material), and doubly gold-bound $\left(\mathrm{y}_{1}, \mathrm{y}_{2}\right.$, and $\mathrm{a}_{3}$ ions in Figure S11 in Supplementary Material) tripeptide CDR indicates that $\mathrm{Arg}$ and $\mathrm{Cys}$ are the gold bonding sites and not the $\mathrm{NH}_{2^{-}}$ terminal amino group or Asp. 


\section{J. Lee et al.: Gold Ion-Peptide Interaction}
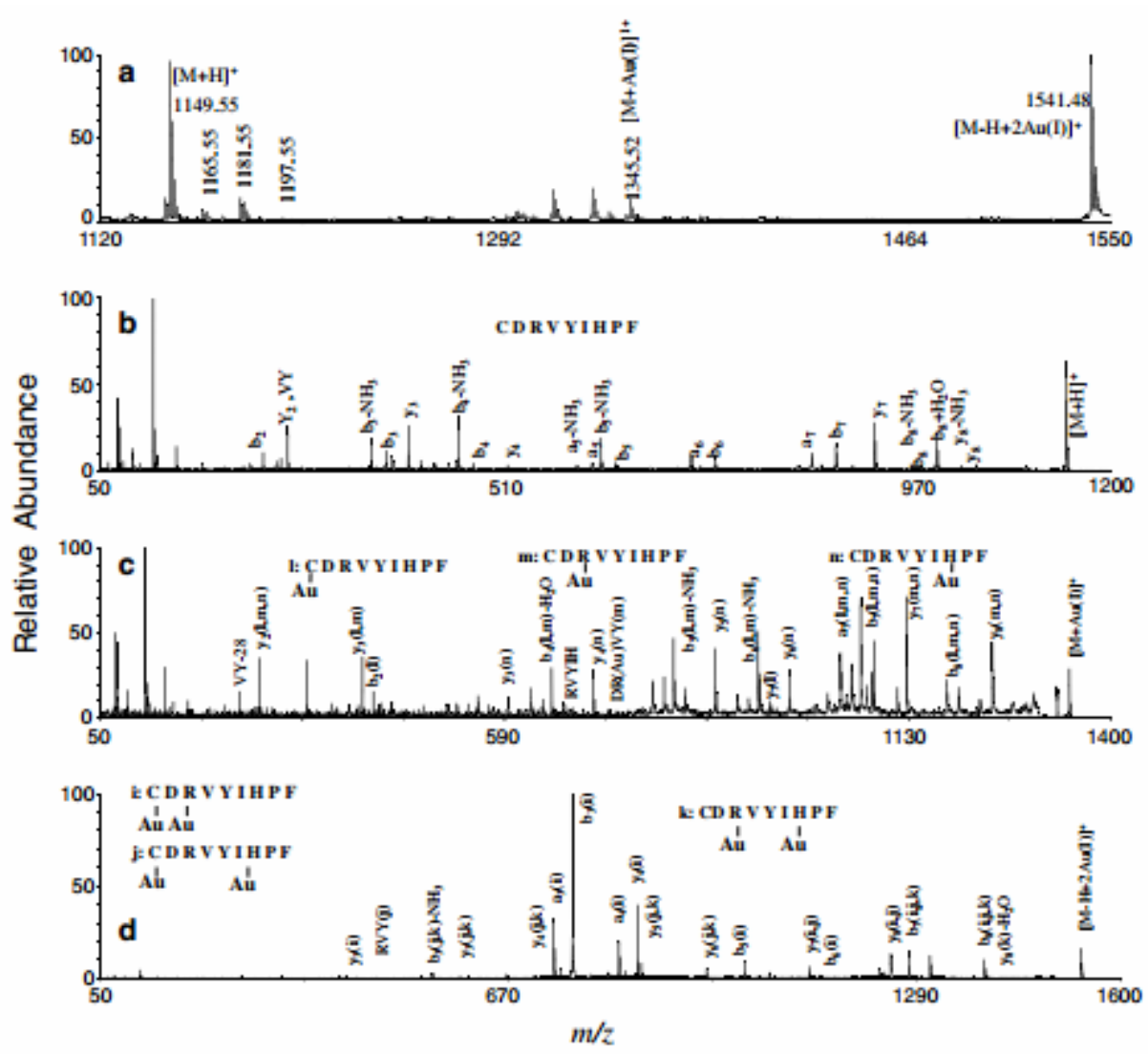

Figure 6. Mass spectra of CysAngiotensin II in the presence of $1 \mathrm{mM} \mathrm{AuCl}_{3}$ : (a) MALDI-TOF mass spectrum; (b) CID mass spectrum (MALDI-TOF/TOF) of [M+H] $]^{+}$; (c) CID mass spectrum (MALDI-TOF/TOF) of $[\mathrm{M}+\mathrm{Au}(\mathrm{I})]^{+}$; (d) CID mass spectrum (MALDI-TOF/TOF) of $[\mathrm{M}-\mathrm{H}+2 \mathrm{Au}(\mathrm{I})]^{+}$

\section{Conclusions}

MADLI-TOF MS and ESI-MS are used successfully to obtain valuable information about the interaction between gold ion and angiotensin peptides. Data shows singly/multiply charged ions of gold ion-angiotensin peptide complexes, which are represented as [peptide+a $\mathrm{Au}(\mathrm{I})+\mathrm{b} \mathrm{Au}(\mathrm{III})+(\mathrm{e}-\mathrm{a}-3 \mathrm{~b}) \mathrm{H}]^{\mathrm{e}}$, where $a, b \geq 0$ and $e$ is charge. Higher amount of the gold ionangiotensin peptide complexes occurs with higher $\mathrm{AuCl}$ or $\mathrm{AuCl}_{3}$ concentration. However, too high a gold concentration encourages aggregation and/or precipitation of gold-peptide complex. Tandem MS data shows that Cys, His, and Arg residues of the peptide seem to be the preferred anchoring sites for gold ion, and the gold- peptide bond is strong enough to survive the CID process. This study reveals that MALDI-TOF MS mainly detects singly charged $\mathrm{Au}(\mathrm{I})$-peptide complexes, indicating that ion formation by MALDI process promotes the reduction of $\mathrm{Au}(\mathrm{IIII})$ to $\mathrm{Au}(\mathrm{I})$. In addition, ESI-MS data shows that gold ion in the gold ion-angiotensin peptide complexes exists in oxidation state of I and/or III, depending on the peptide used. Redox processes are not uncommon for gold ionpeptide systems and gold ion containing compounds [28, 6668]. Gold ions in the Au-angiotensin II and $\mathrm{Au}-$ CysAngiotensin II complexes exit primarily in oxidation state of III and I, respectively. The detection of the formation of different gold ion-angiotensin peptide complexes with different abundances suggests that gold containing anticancer drugs may interact differently with various peptides/proteins. This may alter functions of peptides/proteins, which inhibits the proliferation and differentiation of tumor cells. MS studies on interactions between gold ion and bigger peptides/proteins, gasphase disulfide bridge cleavages with gold [53, 54], and catalytic reactions by gold [69] are underway in this laboratory.

\section{Acknowledgments}

The authors gratefully acknowledge the support of the Research Resources Center at the University of Illinois, Chicago. 


\section{J. Lee et al.: Gold Ion-Peptide Interaction}

\section{References}

1. Kelland, L.: The Resurgence of Platinum-Based Cancer Chemotherapy. Nature Rev Cancer 7, 573-584 (2007)

2. Alderden, R.A., Hall, M.D., Hambley, T.W.: The Discovery and Development of Cisplatin. J. Chem. Ed 83, 728-734 (2006)

3. Lovejoy, K.S., Lippard, S.J.: Non-Traditional Platinum Compounds for Improved Accumulation, Oral Bioavailability, and Tumor Targeting. Dalton Trans. 10651-10659 (2009)

4. Garbutcheon-Singh, K.B.: Grant M.P, Harper B.W., Krause-Heuer A. M., Manohar M., Orkey N., Aldrich-Wright J.R.: Transition metal based anticancer drugs. Curr. Top. Med. Chem. 11, 521-542 (2011)

5. Bergama, A., Sava, G.: Ruthenium Anticancer Compounds: Myths and Realities of the Emerging Metal-Based Drugs. Dalton Trans. 40, $7817-$ $7823(2011)$

6. Wang, C., Shih, W., Chang, H., Kuo, Y., Hung, W., Ong, T., Li, W.: Preparation and Characterization of Amino-Linked Hetercyclic Carbene Pelladium, Gold, and Silver Complexes and Their Use as Anticancer Agents that Act by Triggering Apoptotic Cell Death. J. Med. Chem. 54, 5245-5249 (2011)

7. Milacic, V., Fregona, D., Dou, Q.P.: Gold Complexes as Prospective Metal-based Anticancer Drugs. Histol Histopathol. 23, 101-108 (2008)

8. Sun, R., Li, C., Ma, D., Yan, J., Lok, C., Leung, C., Zhu, N., Che, C.: Stable Anticancer Gold(III)-porphyrin Complexes: Effects of Porphyrin Structure. Chemistry 16, 3097-3113 (2010)

9. Ronconi, L., Aldinucci, D., Dou, Q.P., Fregona, D.: Latest Insights into the Anticancer Activity of Gold(III)-dithiocarbamato Complexes.

Anticancer Agents Med. Chem. 10, 283-292 (2010)

10. Chow, K.H., Sun, R., Lam, J., Li, C., Xu, A., Ma, D., Abagyan, R., Wang, Y., Che, C.: A Gold(III) Porphyrin Complex with Antitumor Properties Targets the Wnt/ $\beta$-catenin Pathway. Cancer Res. 70, 329 337 (2010)

11. Tu, S., Sun, W.R., Lin, M., Tao, C.J., Zou, B., Gu, Q., Kung, H., Che, C., Wong, B.: Gold (III) Porphyrin Complexes Induce Apoptosis and Cell Cycle Arrest and Inhibit Tumor Growth in Colon Cancer. Cancer $115,4459-4469$ (2009)

12. Ott, I.: On the Medicinal Chemistry of Gold Complexes as Anticancer Drugs. Coord. Chem. Rev. 253, 1670-1681 (2009)

13. Sun, R.W., Che, C.: The Anti-cancer Properties of Gold(III) Compounds with Dianionic Porphyrin and Tetradentate Ligands. Coord. Chem. Rev. 253, 1682-1691 (2009)

14. Bindolia, A., Maria Pia Rigobello, M.P., Scutari, G., Gabbiani, C., Casini, A., Messori, L.: Thioredoxin Reductase: A Target for Gold Compounds Acting as Potential Anticancer Drugs. Coord. Chem. Rev 253, 1692-1707 (2009)

15. Milacic, V., Dou, Q.P.: The Tumor Proteasome as a Novel Target for Gold(III) Complexes: Implications for Breast Cancer Therapy. Coord. Chem. Rev. 253, 1649-1660 (2009)

16. Gabbiani, C., Casini, A., Messori, L.: Gold (III) Compounds as Anticancer Drugs. Gold Bulletin 40, 73-81 (2007)

17. Messori, L., Marcon, G., Cinellu, M., Agostina, M., Coronnello, M., Mini, E., Gabbiani, C., Chiara, Q., Orioli, P., Pierluigi, P.: Solution Chemistry and Cytotoxic Properties of Novel Organogold (III) Compounds. Bioorg. Med. Chem. 12, 6039-6043 (2004)

18. Messori, L., Marcon, G., Orioli, P.: Gold (III) Compounds as New Family of Anticancer Drugs. Bioinorg. Chem. Appl. 1, 177-187 (2003)

19. Yang, T., Tu, C., Zhang, J., Lin, L., Zhang, X., Liu, Q., Ding, J., Xu, Q., Guo, Z.J.: Novel Au (III) Complexes of Aminoquinoline Derivatives: Crystal Structure, DNA Binding and Cytotoxicity Against Melanoma and Lung Tumour Cells. Chem. Soc., Dalton Trans. 17, 3419-3424 (2003)

20. Marcon, G., Messori, L., Orioli, P.: Gold (III) Complexes as a New Family of Cytotoxic and Antitumor Agents. Exp. Rev. Antican. Ther. 2, 337-346 (2002)
21. Chapkanov, A., Miteva, Y., Kolev, T., Spiteller, M., Koleva, B.: New $\mathrm{Au}$ (III), Pt (II) and Pd (II) Complexes with Pentapeptide Glycyl-glycyl(L)-methyonyl-glycyl-glycine and Their Interaction with Calf Thymus DNA. Protein Pept Lett. 17, 228-237 (2010)

22. Kolev, T.S., Koleva, B.B., Zareva, S.Y., Spiteller, M.: Au (III)complexes of the Alanyl-containing Peptides Glycylalanine and Glycylalanylalanine-Synthesis, Spectroscopic and Structural Characterization. Inorg. Chim. Acta 359, 4367-4376 (2006)

23. Kolev, T., Ivanova, B.B., Zareva, S.Y.: An Au(III) Complex of GlycylS serine: a Linear Polarized IR and 1H- and 13C-NMR Investigation. J. Coord. Chem. 60, 109-115 (2007)

24. Koleva, B.B., Kolev, T., Zareva, S.Y., Spiteller, M.: The Dipeptide Alanylphenylalanine (H-Ala-Phe-OH)-Protonation and Coordination Ability with Au (III). J. Mol. Struct. 831, 165-173 (2007)

25. Ivanova, B.B.: Solid-state Linear-dichroic Infrared Spectroscopic Analysis of the Dipeptide S-Phe-S-Phe and Its Mononuclear Au (III) Complex. J. Coord. Chem. 58, 587-593 (2005)

26. Wienken, M., Lippert, B., Zangrando, M., Randaccio, L.: Glycyl-Lhistidine Dipeptide Complexes. Preparation and X-ray Structures of Monomeric and Cyclic Tetrameric Species. Inorg. Chem. 31, 1983-1985 (1992)

27. Best, S.L., Chattopadhyay, T.K., Djuran, M.I., Palmer, R.A., Sadler, P., Sovago, I., Varnagy, M.: Gold(III) and Palladium(II) Complexes of Glycylglycyl-L-histidine: Crystal Structures of [AuIII(Gly-Gly-LHis-H2)] $\mathrm{Cl} \times \mathrm{xH} 2 \mathrm{O}$ and [PdII(Gly-Gly-L-His-H-2)]x1.5H2O and His $\varepsilon$ - NH Deprotonation. J. Chem. Soc., Dalton Trans 15, 2587-2596 (1997)

28. Mendes, F., Groessl, M., Nazarov, A.A., Tsybin, Y.O., Sava, G., Santos, I., Dyson, P.J., Casini, A.: Metal-Based Inhibition of Poly(ADP-ribose) Polymerase -The Guardian Angel of DNA. J. Med. Chem. 54, 2196-2206 (2011)

29. Whitehouse, C.M., Dreyer, R.N., Yamashita, M., Fenn, J.B.: Electrospray Interface for Liquid Chromatographs and Mass Spectrometers.Anal. Chem. 57, 675-679 (1985)

30. Banks Jr., J.F., Whitehouse, C.M.: Electrospray Ionization Mass Spectrometry. Methods Enzymol. 270, 486-519 (1996)

31. Karas, M., Hillenkamp, F.: Laser Desorption Ionization of Proteins with Molecular Masses Exceeding 10000 Daltons. Anal. Chem 60, 22992301 (1988)

32. Beavis, R.C., Chait, B.T.: Matrix-Assisted Laser Desorption Ionization Mass Spectrometry of Proteins. Methods Enzymol 270, 519-551 (1996)

33. Schalley, C.A., Springer, A.: Noncovalent Complexes with peptides and Proteins. Mass Spectrometry and Gas-Phase Chemistry of Noncovalent Complexes, pp. 359-422. John Wiley and Sons, Hoboken, NJ (2009)

34. Wu, Z., Fernandez-Lima, F.A., Perez, L.M., Russell, D.H.: A New Copper Containing MALDI Matrix That Yields High Abundances of $[$ Peptide + Cu]+ Ions. J. Am. Soc. Mass Spectrom. 20, 1263-1271 (2009)

35. Wyttenbach, T., Liu, D., Bowers, M.T.: Interactions of the Hormone Oxytocin with Divalent Metal Ions. J. Am. Chem. Soc. 130, 5993-6000 (2008)

36. Schafer, M., Dreiocker, F., Budzikiewicz, H.: Collision-induced Loss of Ag+ Adducts of Alkylamines, Aminocarboxylic Acids, and Alkyl Benzyl Ethers Lead Exclusively to thermodymanically favored Product Ions. J. Mass Spectrom. 44, 278-284 (2009)

37. Li, H.B., Siu, K.W.M., Guevremont, R., LeBlanc, J.C.Y.: Complexes of Silver(I) With Peptides and Proteins as Produced in Electrospray Mass Spectrometry. J. Am. Soc. Mass Spectrom. 8, 781-792 (1997)

38. Liu, H., Håkansson, K.: Divalent Metal Ion-Peptide Interactions Probed by Electron Capture Dissociation of Trications. J. Am. Soc. Mass Spectrom. 17, 1731-1741 (2006)

39. Lagarrigue, M., Bosse'e, A., Afonso, C., Fournier, F., Bellier, B., Tabet, J.: Diastereomeric Differentiation of Peptides with CuII and FeII Complexation in an Ion Trap Mass Spectrometer. J. Mass Spectrom. 41, 1073-1085 (2006) 


\section{J. Lee et al.: Gold Ion-Peptide Interaction}

40. Bluhm, B.K., Shields, S.J., Bayse, C.A., Hall, M.B., Russell, D.H.: Determination of Copper Binding Sites in Peptides Containing Basic Residues: Combined Experimental and Theoretical Study. Int. J. Mass Spectrom. 204, 31-46 (2001)

41. Shields, S.J., Bluhm, B.K., Russell, D.H.: Novel Method for $[\mathrm{M}+\mathrm{Cu}]+$ Ion Formation by Matrix-Assisted Laser Desorption Ionization. Int. J. Mass Spectrom. 183, 185-195 (1999)

42. Wong, C.K.L., Chan, T.W.D.: Cationization Processes in MatrixAssisted Laser Desorption/Ionization Mass Spectrometry: Attachment of Divalent and Trivalent Metal Ions. Rapid Commun. Mass Spectrom. 11, 513-519 (1997)

43. D'Agostino, A., Colton, R., Traeger, J.C., Canty, A.J.: An Electrospray Mass-Spectrometric Study of Organomercury(II) and Mercuric interactions with Peptides Involving Cysteinyl Ligands. Eur. Mass Spectrom. 2, 273 285 (1996)

44. Hu, P.F., Gross, M.L.: Gas-phase Interactions of Transition-metal Ions and Di- and Tripeptides: A Comparison with Alkaline-earth-metal-ion Interactions. J. Am. Chem. Soc. 115, 8821-8828 (1993)

45. Hu, P.F., Loo, J.A.: Gas Phase Coordination Properties of $\mathrm{Co} 2+$ and $\mathrm{Ni} 2+$ with Histine-containing Peptides. J. Am. Chem. Soc. 117, 11314-11319 (1995)

46. Reiter, A., Adams, J., Zhao, H.: Intrinsic (Gas-Phase) Binding of Co2+ and $\mathrm{Ni2}+$ by Peptides-A Direct Reflection of Aqueous-Phase Chemistry. J. Am. Chem. Soc. 116, 7827-7838 (1994)

47. Cerda, B., Conett, L., Wesdemiotis, C.: Probing the Interaction of Alkali and Transition Metal Ions with Bradykinin and its DesArginine derivatives via Matrix-Assisted Laser Desorption/Ionization and Postsource Decay Mass Spectrometry. Int. J. Mass Spectrom. 193, 205-226 (1999)

48. Loo, J.A., Hu, P.: Interaction of Angiotensin peptides and Zinc Metal Ions Probed by Electrospray Ionization Mass Spectrometry. J. Am. Soc. Mass Spectrom. 5, 959-965 (1994)

49. Pacheco, E.A., Tiekink, E.R.T., Whitehouse, M.W.: Gold Compounds and Their Applications in Medicine. Gold Chemistry: Applications and Future Directions in the Life Sciences, pp. 283-319. Wiley-VCH Verlag GmbH \& Co. KgaA, Weinheim, Germany (2009)

50. Deponte, M., Urig, S., Arscott, L.D., Fritz-Wolf, K., Re’au, R., HeroldMende, C., Koncarevic, S., Meyer, M., Davioud-Charvet, E., Ballou, D.P., Williams, C.H., Katja Becker, K.: Mechanistic Studies on a Novel, Highly Potent Gold-phosphole Inhibitor of Human Glutathione Reductase. J. Biol. Chem. 280, 20628-20637 (2005)

51. Talib, J., Beck, J.L., Ralph, S.F.: A Mass Spectrometric Investigation of the Binding of Gold Antiarthritic Agents and the Metabolite [Au(CN)2] to Human Serum Albumin. J. Biol. Inorg. Chem. 11, 559-570 (2006)

52. Zou, J., Tayor, P., Dornan, J., Robinson, S.P., Walkinshaw, M.D., Salder, P.J.: First Crystal Structure of a Medicinally Relevant Gold Protein Complex: Unexpected Binding of $[\mathrm{Au}(\mathrm{Pet} 3)]+$ to Histidine. Angew. Chem. Int. Ed. 39, 2931-2934 (2000)

53. Lioe, H., Duan, M., O'Hair, R.A.J.: Can Metal Ions be Used as Gas Phase Disulfide Bond Cleavage Reagents? A Survey of Coinage Metal Complexes of Model Peptides Containing an Intermolecular Disulfide Bond. Rapid Commun. Mass Spectrom. 21, 2727-2733 (2007)

54. Gunawardena, H.P., O'Hair, R.A.J., McLuckey, S.A.: Selective Disulfide Bond Cleavage in Gold (I) Cationized Polypeptide Ions Formed via Gas-Phase Ion/Ion Cation Switching. J. Proteome Res. 5, 2087-2092 (2006)

55. Karas, M., Kruger, R.: Ion Formation in MALDI: The Cluster Ionization Mechanism. Chem. Rev. 103, 427-439 (2003)

56. Schwerdtfeger, P., Lein, M.: Theoretical Chemistry of Gold-from Atoms to Molecules, Clusters, Surfaces, and the Solid State. Gold Chemistry: Applications and Future Directions in the Life Sciences. Wiley-VCH Verlag GmbH \& Co. KGaA: Weinheim, Germany; pp. 183-246 (2009)
57. Trimpin, S., Ren, Y., Wang, B., Lietz, C.B., Richards, A.L., Marshall, D.D., Inutan, E.D.: Extending the Laserspray Ionization Concept to Produce Highly Charged Ions at High Vacuum on a Time-of-Flight Mass Analyzer. Anal. Chem 15, 5469-5475 (2011)

58. Karas, M., Gluckmann, M., Schafer, J.: Ionization in Matrix-Assisted Laser Desorption/Ionization: Singly Charged Molecular Ions are the Lucky Survivors. J. Mass Spectrum. 35, 1-12 (2000)

59. Medzihradszky, K.F.: Peptide Sequence Analysis. Methods Enzymol. 402, 209-244 (2005)

60. Paizs, B., Suhai, S.: Fragmentation Pathways of Protonated Peptides. Mass. Spectrom. Rev. 24, 508-548 (2005)

61. Wells, J.M., McLuckey, S.A.: Collision-Induced Dissociation (CID) of Peptides and Proteins. Methods Enzymol. 402, 148-185 (2005)

62. Best, S.L., Chattopadhyay, T.K., Djuran, M.I., Palmer, R.A., Salder, P.J., Sovago, I., Varnagy, M.: Gold(III) and Palladium(II) Complexes of Glycylglycyl-L-Histidine: Crystal Structures of [AuIII(Gly-Gly-L-His-H2) $\mathrm{Cl} \cdot \mathrm{H} 2$ and [PdII(Gly-Gly-L-His-H-2)] $1.5 \mathrm{H} 2$ and HiseNH deprotonation. J. Chem. Soc., Dalton Trans. 15, 2587-2596 (1997)

63. Sigel, H., Martin, R.B.: Coordinating Properties of the Amide Bond. Stability and Structure of Metal Ion Complexes of Peptides and Related Ligands. Chem. Rev. 82, 385-426 (1982)

64. Hutchens, T.W., Allen, M.H., Li, C.M., Yip, T.: Occupancy of a C2-C2 Type "Zinc-Finger" Protein Domain by Copper. Direct Observation by Electrospray Ionization Mass Spectrometry. FEBS Lett. 309, 170-174 (1992)

65. Hutchens, T.W., Allen, M.H.: Electrospray Ionization Mass Spectrometry for the Detection of Discrete Peptide/Metal-Ion Complexes Involving Multiple Cysteine (Sulfur) Ligands. Rapid Commun. Mass Spectrom. 6, 308-312 (1992)

66. Casini, A., Cinellu, M.A., Minghetti, G., Gabbiani, C., Coronnello, M., Mini, E., Messori, L.: Structural and Solution Chemistry, Antiproliferative Effects, and DNA and Protein Binding Properties of a Series of Dinuclear Gold(III) Compounds with Bipyridyl Ligands. J. Med. Chem. 49, 55245531 (2006)

67. Gimeno, M.C.: The Chemistry of Gold. Modern Supramolecular Gold Chemistry: Gole-Metal Interactions and Applications, pp. 1-63. WileyVCH Verlag GmbH \& Co. KGaA, Weinheim, Germany (2008)

68. Puddephatt, R.J.: The Chemistry of Gold. Elsevier, New York (1978)

69. Lein, M., Rudolph, M., Hashmi, S.K., Schwerdtfeger, P.: Homogeneous Gold Catalysis through Relativistic Effects: Addition of Water to Propyne. Organometallics 29, 2206-2210 (2010) 